\title{
Plot Reconstitution and Land Readjustment
}

\author{
Vandana Chandrakar ${ }^{1}$, Bhawana Girepunje ${ }^{2}$, Shubham Yadav ${ }^{3}$, Sonam Vaidya ${ }^{4}$ \\ Department of Urban Planning University Teaching Department Chhattisgarh Swami Vivekanand \\ Technical University Bhilai (C.G.) India \\ Corresponding Author: Email id: 25vandanachandrakar@gmail.com, bhawanagirepunje@gmail.com, \\ yshubham0819@gmail.com Sonamvd31@gmail.com
}

\begin{abstract}
For many decades, several states of India have utilized the plot reconstitution and land readjustment technique for managing urban development. As land is a limited resource subsequently well-organized land management techniques are crucial for its acquisition and development. The land readjustment process is one exemplary land assembly tool, which many countries including Japan, Germany have adopted and it's known as town planning scheme in India. This is the idea of reshaping or re-plotting a parcel of land and developing it with basic infrastructures, amenities and services like roads, parks, social infrastructure and utilities. Rapid urbanization in the developing world is causing a lack of municipal resources with public services falling further and further behind demand. New and redesigned settlements are needed but appropriate plots of land are not usually available. More efficient distribution of land is required. Land readjustment is one of the approaches to deal with these urbanization problems. This paper attempts to explore the use of this innovative means of land development with a view to assessing the potentiality and constraints in the land readjustment process and its use and identifying critical areas where further refinements would be desirable.
\end{abstract}

Key Words: Land Banking Land Readjustment Plot Reconstitution Land Pooling Land Sharing Transfer of Development Rights.

Broad Area- Urban Planning.

Sub-Area- Land Management Technique.

\section{Introduction}

The land readjustment (LR) is not new and has been present since the late nineteenth century. The essence of this concept is to service the land with infrastructure and amenities in peri-urban areas, which are likely to grow haphazardly in the absence of any regulated plan [1-3]. States undertake this by appropriating and consolidating a portion of land from the land rights holders for infrastructure development and returning the replotted, reshaped, and regularized parcels of serviced land. This helps in achieving multiple objectives-providing infrastructure and public facilities in an organized manner, increasing the usage and values of land, and containing haphazard development through systematic land use planning.

Japan mainstreamed the land readjustment approach in its urban development policy, after Germany and the UK pioneered it. Japan has used the technique for more than a century, institutionalizing it in the early nineteenth century and later enacting it through the Land Readjustment Law in 1954 to address the post-World War II urban development challenges arising from massive destruction. In India, people refer to it as land pooling, land consolidation, but most commonly the Town Planning Scheme (TP Scheme). It follows the same basic concept of land readjustment as in Japan but 
differs in use; for example, India mostly applies it to peri-urban areas and uses it scantly for core area revitalization and postdisaster areas. Furthermore, only the designated public authority implements it, with no or limited involvement of the private sector.

This research paper tries to explain the plot reconstitution and land readjustment process and potential use of land readjustment in urban planning.

\subsection{Land Management Technique}

Under the present situation of the land market where much land is in private hands government intervention can be through the mechanism listed below

\subsubsection{Land Banking}

Land banking involves the advance acquisition of land for government use or large-scale public ownership of undeveloped land for further use. A revolving fund can be developed by acquiring fringe areas at low prices developing it and disposing of it at a higher price. With the surplus money thus generated further parcels of land can be acquired. In Sweden and the Netherlands, it has been possible to maintain government monopoly on the conversion process. Developing countries like India however lack such an institutional framework and administrative resources. Thus, it is difficult to implement such a concept. The Urban Land Ceiling (and Regulation) Act (ULCRA) 1976 has been able to achieve very little in India.

The National Commission on Urbanization has observed that it has failed to mop up excess vacant land and to generate sufficient land for the economically weaker section.
Moreover, the freezing of land caused by the act has further increased land prices.

\subsubsection{Land Readjustment}

This concept has been successfully tried in Korea, Taiwan and so on. The process can start with either the government or the people (at least $80 \%$ of landowners) petitioning for readjustment of fringe land from rural to urban category. A site plan is prepared, infrastructure and services are provided and that enhances the market value of new sites. The government retains just enough plots to repay the costs of infrastructure and services. Original owners get back the remaining sites in proportion to initial contribution. Other tools in hands of the government are land-use regulations, subdivision regulations; etc. The National Commission on Urbanization has observed that it has failed to mop up excess vacant land and to generate sufficient land for the economically weaker section. Moreover, the freezing of land caused by the act has further increased land prices.

\subsubsection{Land Pooling}

This is another form of land acquisition. Private land is acquired by a public authority with multiple plots and owners. The public authority then consolidates the area, organizes the plots and is given back to the original owners in proportion to their original plot size. The reduced area is compensated by the increase in land value due to development.

\subsubsection{Land Sharing}

It has been pointed out that the security of tenure is the single most important factor for poor people to improve their living conditions. Often government action on-site development increases the land value 
especially when such actions are taken in areas with slum and squatter settlement areas. In an attempt to establish the land rights in slum and squatter areas the government is often caught as an arbiter between the slum dwellers and the landlord. The option available in that case is a spectrum of five options as follows:

- Resist eviction and occupy the entire land.

- Negotiate on a land-sharing agreement resettle on a part of the land making the rest of the land available for the development.

- Agree to resettle on an alternative site.

- Agree to compensation for land clearing

- Leave the site without any compensation.

Since land is a limited natural resource for human activities it requires effective management systems. Rapid urbanization requires serviceable land for public and private needs. Traditionally not only in Europe but also in the other parts of the world the continued subdivision of land over the years has resulted in the fragmenting of land parcels into incredibly small units. Since land is basic and tenaciously held, remedies to the fragmenting of land parcels must be deliberately carefully planned and executed both by government and private bodies. However, land readjustment is one of the urban planning processes that can provide these requirements.

Land readjustment (LR) may be defined as a land management tool that assists in orderly urban development by the contribution of landowners. The main objective of LR is to convert irregularly developed land parcels into suitable forms according to town planning requirements. It has great advantages in solving the land-use problems in urban areas but the current implementations are still faced with some limitations. These included technical limitations in handling the wealth of data, economical limitations in compensation for acquiring land and social limitations in minimizing the inconvenience and conceivable injustices. Therefore, the reexamination of these issues is essential.

\subsection{The Concept of Land Readjustment (Plot Reconstitution)}

"LR is a technique for managing the urban development of urban-fringe lands whereby a group of separate land parcels is assembled for their unified planning servicing and subdivision as a single estate and redistribution of new building lots back to the original landowners" [4].

"The process primarily takes the rural or unplanned urban land and reallocates it in a more effective use concerning town planning requirements" [5]. However, as an urban land management tool LR easily provides the land in a reorganized way for public and private needs. Particularly the main objectives with LR are:

- The provision of land required for public use such as streets parks hospital school from all participating landowners in a project area. - To create such plots suitable for building use according to the rules of the zoning plan.

- To transfer the existing land rights on the previous sites to the new replotted sites while carrying out the urban development.

\subsubsection{Procedures in Land Readjustment (Plot reconstitution)}

LR projects are usually undertaken by a local government following related legislation procedures. A typical LR process begins with the preparation of a zoning plan by the 
municipality. "On the zoning plan within the site blocks formed by the streets lots are allocated for private development. The area for public use is then determined by measuring the square meters in the planned streets parks and so forth and comparing it to the total area of the project" [6]. In other words, all land parcels within a project area are grouped and a percentage of each land parcel is calculated to determine a contribution to public areas. This percentage depends on the size of the project area and the total size of the required public-use areas. The remaining land is then reallocated within the blocks defined by the plan. To do this first each site block is subdivided into suitable new lots and land redistribution is carried out. The basic principle in the distribution is to keep land in nearby its original location at least in the same block.

The land readjustment process indicates the inherent and complex equity problem in the allocation of plots and the provision of financial compensation. Before the project the plots may have different physical shapes and economic value. Some plots may be hilly and unsuitable for urban use while others may be very suitable for agricultural production but expensive for constructing housing.

Even during the period of construction, the impact will differ as these typically large projects will begin in one end of the project area and it may take years before the other end is completed and all services provided. Some landowners such as farmers may lose their income opportunities earlier if they are located where the project starts. After the project there may be differences owing to the allowed land use and the allocation of plots.
"Residential or commercial plots with highdensity land use as well as plots located close to infrastructure hubs commercial activities and along main roads will have high land values. The solution for this equity problem may differ among countries using the land readjustment method although research shows that there are many similarities" [7].

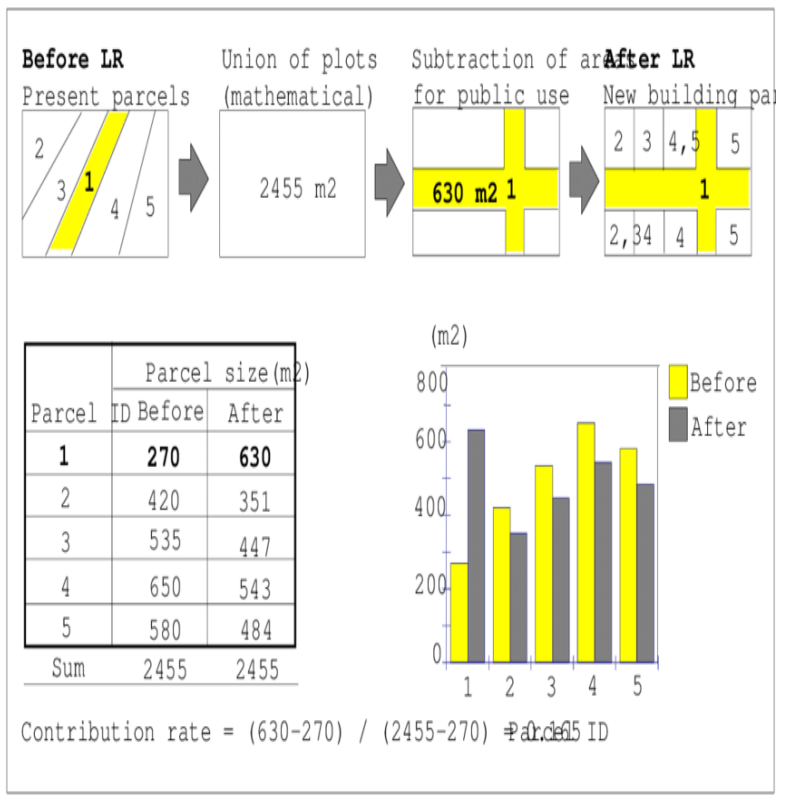

Fig. $1 \mathrm{~A}$ land re-adjustment process (Tahsin Yomralioglu 1993)

For instance, the distribution of revenues and costs is often based on either the present value (often agricultural land use) or the size of the land before land readjustment thereby not taking into consideration how appropriate the plots are for urban use.

Land readjustment is an attractive method to influence the location and timing of new urban development since it is becoming increasingly difficult to obtain public support for the use of expropriation for land development and infrastructure provision. The method is typically supported and sometimes even initiated by the landowners 
since they would make a considerable profit on the project.

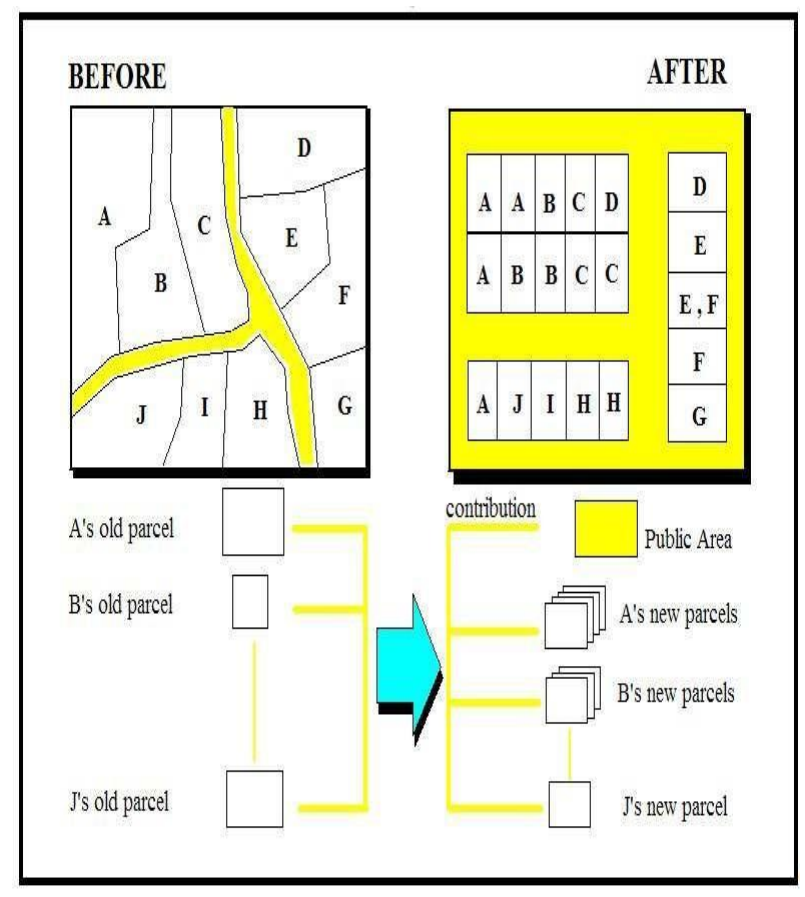

Figure 2 Mechanism of Land Readjustment [5]

Contrary to the obvious alternative methods for city development, land banking and expropriation it also avoids the costly and unpopular government procedure of acquiring land. Unlike expropriation land readjustment will return a major part of the land to the landowner. Ideally a partnership for development should be formed between the public sector and the landowners. It is therefore very important that close links are established during the project. It also provides an opportunity for the provider of infrastructure and services to recover the incurred costs as well as to get access to land for this purpose. As cost recovery is a major obstacle for municipal governments in most developing countries this would probably be the most important component. Land readjustment requires that the land ownership situation is clarified, and an accurate land registration system provided. This should also lead to increased public revenues from property taxation. It could provide increased equity inland distribution. Not only among the landowners within the area but it could also be a means of providing access to land for low-income housing. In the above thoughts there are several problems with the land readjustment technique. First it provides an opportunity for landowners to develop their land but present systems do not force the development of land. In many countries with very high demand for land such as Turkey it has become increasingly common that landowners use their land as a savings and investment instrument and this has contributed to increases in land values and land speculation.

Furthermore, another major incentive for landowners to encourage high land values is that the provision of infrastructure and services is financed by the sale of land. As there are no incentives to maintain low prices on land and no other built-in mechanism for inexpensive housing the method has been criticized for not being effective in reducing the huge shortage of low-income housing in most cities. The problem could however be alleviated if the landowners' gain was somewhat reduced and a larger proportion of the land was allocated to the public sector for purposes such as low-income housing. While it is important to maintain the incentive for landowner participation it can be argued that the profit margin is unreasonably high and that the role of the public sector as a partner should be recognized in sharing the profit. The public sector should therefore aim for more than cost recovery. The concept of the land readjustment technique is based on 
private-public cooperation and negotiation; it requires large human resources both in terms of numbers and qualifications. In particular skilled negotiators and appraisers must be available. In most developing countries there is a shortage of skilled staff in the Government especially at the municipal government level.

\section{Nominal asset land valuation}

The nature of land readjustment constrains the cadastral parcels to transform into new site lots. Hence within a land readjustment project area not only existing cadastral boundaries are changed but also the economic values of the parcels. From the economic point of view these changes very much affect the landowners. Land value profiles for the owners can be different before and after the project. Especially after full implementation of the new plan the land market-values increase greatly within the project region so that landowners can obtain new and different benefits from the project. In general, the land valuation issue appears after the project. Most of the objections come from landowners about land valuation. They claim that equitable benefits are not obtained after the project. This is due in part to the fact that during the project the planners have difficulty estimating and distributing the benefits which a land-use plan may bring. Land market-values are usually used to evaluate these benefits. However, in some countries different approaches have been practiced dealing with land evaluation procedures. In Australia for example the land valuation board is established to determine the market value of the land parcels. After the project a cash adjustment procedure is applied to the involved landowners. In
Germany annual real-market indexes are considered before and after the project. If the land values are quite homogenous in the project area, then the values are ignored during the project. In the Japanese approach the land is evaluated by the site utilities. Land values are calculated using the index applying the same standard before and after the project. However, in Turkey land evaluation is not considered during any steps of the process. In general, lack of information funds shortage of technical and administrative personnel delay implementation of the needed large-scale land valuation activities. However, the determination of a land parcel value depends on several physical and economic characteristics that must be taken into consideration very carefully in a land valuation procedure. Some of these characteristics are intrinsic to the land others are external or environmental factors. These factors can be determined objectively but there is always a certain degree of subjectivity that is difficult to measure in the valuation process.

To improve the benefits obtained from a land readjustment process a new approach proposed by Yomralioglu [5] was used. Based on this a value-based urban land readjustment model was applied to the land rights transferring process in this study. Due to the difficulty of collecting real-market value data numerical parameters are intended to be calculated and used for each land parcel rather than using the real market value. The proposed model analyses each geographical unit of a land parcel concerning some selected substantial and insubstantial land valuation factors. Each of these factors is 
mathematically expressed and the nominal asset values for the parcels are determined with the combination of these factors. It has to be mentioned that in this model the term value is used as a single unit figure which represents a land parcel's worth when compared with others. Therefore, the meaning of value is a numerical parameter of each land parcel rather than a real-market value. "To determine this parameter some land valuation factors which may affect the total perceived value of a land parcel are spatially examined. To accomplish the required analysis procedures the spatial analysis capabilities of a GIS are used" by Yomralioglu and Nisanci [8]. In reality it is almost impossible to determine the exact value of a land parcel. However sufficient estimation can be done by analyzing a certain amount of land characteristics in an objective way.

In this work rather than dealing with the realmarket prices the qualitative and quantitative characteristics of individual land parcels have been examined. To determine the value of a land parcel some land valuation criteria are selected and formulated so that parcel values are assigned by the numerical parameters rather than real-market values. These parameters are derived from a combination of the selected land valuation factors which can be spatially analyzed.

\section{Classification of land valuation factors and calculation process}

To make adequate value estimation for a land parcel in the project area many tangible and intangible land valuation factors should be considered during the process. The determination and classification of these valuation factors are difficult because the characteristics of these factors can be objective and subjective changing according to a person's desires. Therefore, the number of land valuation factors cannot be limited but at least some of the land valuation factors are considered and analyzed concerning the land readjustment project stages as before and after. Because the conditions are different before and after the project different land valuation factors are considered in both stages. Based on the nominal land valuation concept land valuation factor analysis is done and the total value of a parcel is determined. In the land readjustment process two main distinction stages must be realized while performing the land valuation analysis.

\subsection{The Role of LR in Urban}

\section{Development}

The concept of LR is primarily based on the increasing of public-use land while the size of private land is decreasing. As a result of this the size of private lands is reduced and becomes smaller but their economic values increase due to the extra developments which the zoning plan brings. Meanwhile new builtup lots are created, and municipalities acquire the public land to install new services as rapidly as they required. "The $L R$ process also provides a great opportunity for the government to simply and inexpensively resurvey the land and demarcate new parcel boundaries. Therefore, the practice of LR can be considered as a way of strengthening the reorganization of cadastral" [9]. "LR is a method by which the city government other designated public bodies or even private associations can participate directly in the process of urbanization and thereby share in its profits" [10]. Besides improving land utilization for the government, it is also a 
significant method for landowners to economically improves the use of their land. However, some benefits of LR for both government and landowners may be given as follows:

\subsection{LR Benefits for the government}

- Compensation expenses for public-use land are greatly reduced so that the provision of public areas is captured more economically

- A zoning plan is realized in a short time and urban land development projects are achieved rapidly

- Tax revenue increases within the project area. This provides an extra source to government

- The land development programs in urban fringe areas are systematically carried out

- The existing cadastral records are updated reorganized and cadastral administration is improved.

\subsection{LR Benefits for landowners}

- After the project land values increase very rapidly and the land becomes more valuable for landowners

- A cadastral parcel is re-shaped and transformed into a sufficient site lot that can be used more economically

- Fragmented small parcels are consolidated into a new building parcel so that land use is maximized

- Because of the effects of the LR project are the same for every landowner dispute about land planning injustices are reduced

- At the end of the project basic public services are supplied to new lots therefore the new social services are brought into the project area
- There is no extra charge to landowners for the project expenses except that they forfeit part of their land. In any case all project expenses are met by the municipalities.

\section{The Issues}

"LR has notable advantages in solving landuse problems for urbanization but some issues affect the adequate use of the process" [11]. Land valuation for example has not been dynamically involved in the entire process. Many substantial criteria that may affect a land parcel's value are ignored during the process. As a result of this inequitable land distribution occurs to the original landholders so that their benefits differ from the project. Due to there not being a standardized land distribution process the planners have difficulty in deciding on the new land parcel locations. Land redistribution itself is a very complex task that requires massive spatial data analysis. Concerning the priorities of the zoning plan and cadastral layouts many questions should be answered by planners. Such questions are how the land will be evaluated; what land characteristics should be considered; who will receive the lots; how will

Landowners be redistributed or be consolidated so that landowners be satisfied and so on. Managing the data flow is also insufficient in the current applications.

Because of poor information management processes the entire procedure is timeconsuming and error prone. This causes some undesirable duplication during the project adding to the expenses of the project. 


\subsection{Characteristics of land} readjustment (Plot reconstitution) in comparison with the land acquisition method and others are as follows

This represents the current land parcels and land-use condition. The land parcels are the cadastral or old parcels that are subject to the land development process.

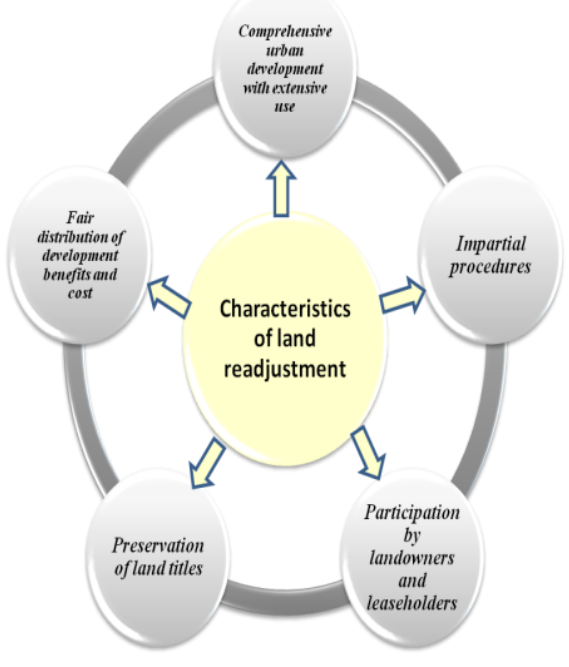

Fig. 3 Characteristics of land readjustment (photograph by Japan Ministry of construction 1997)

These are the only parcels that are affected by the project. They are also considered as the original input parcels of a land readjustment project. In this stage all land parcels are evaluated and classified by their existing suitability without referring to the urban land scheme.

\subsection{Comprehensive}

urban

\section{development with extensive use}

Land readjustment is urban development measures that construct urban facilities such as roads parks and utilities and develop building lots in a project area. And Land readjustment is also an urban development measure that is flexible in the objective size area and development grade.

\subsection{Fair distribution of development benefits and cost}

Each landowner and leaseholder shoulder fairly land and expenses for the development of urban facilities. On the other hand, the benefits accruing from the development are also fairly distributed among then. The land readjustment project is oriented to selffinancing.
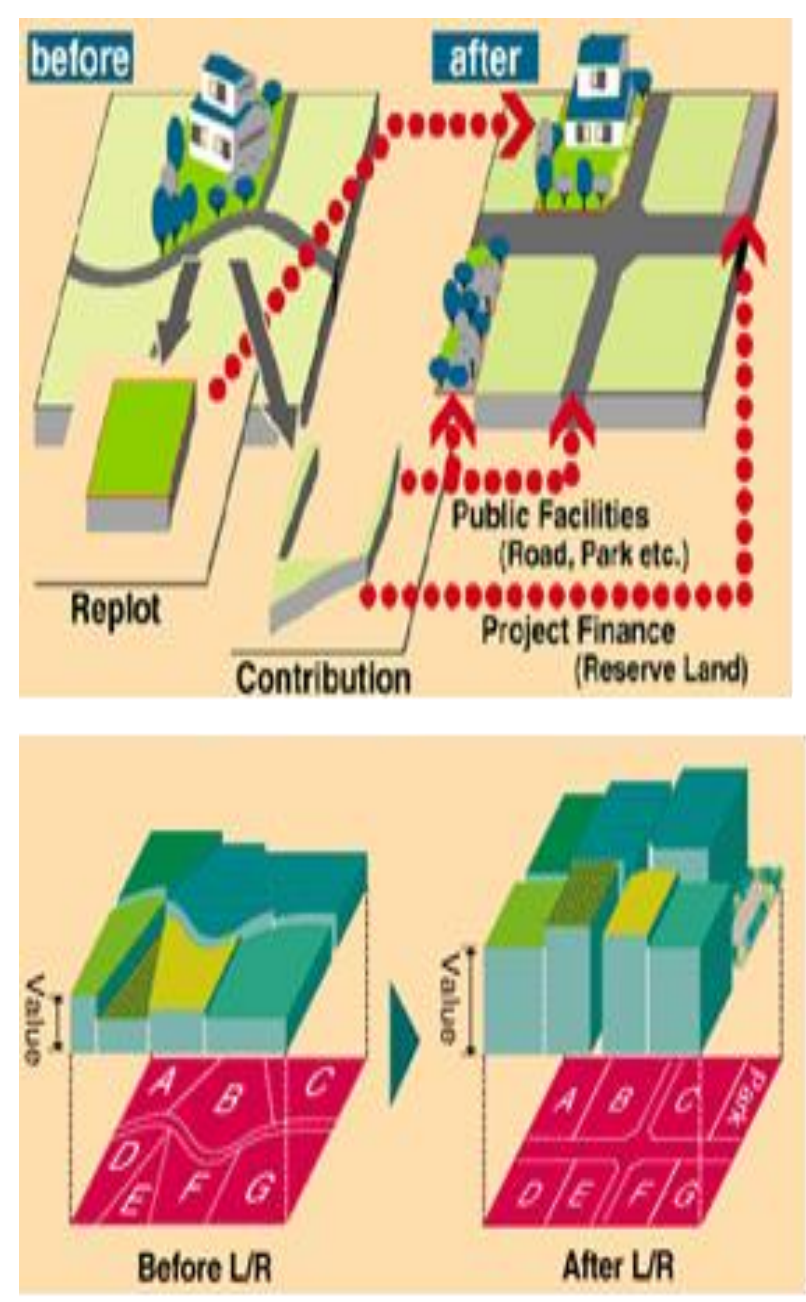

Fig 4 General mechanism of land readjustment (LR)

[13]

\subsection{Preservation of land titles}

Under land readjustment land titles before a project are transferred to replots. Therefore, land titles are preserved during a project and a previous regional community remains. 
Participation by landowners and leaseholders, landowners and leaseholders can participate in a project. Land readjustment is a democratic measure to reflect their views on the project.

\subsection{Impartial procedures}

The procedures for a project are regulated ensuring transparency. In the case of implementation by local government an advisory council of representatives of landowners and leaseholders follows the procedures.

In the case of implementation by cooperative general meetings of landholders and leaseholders are organized.

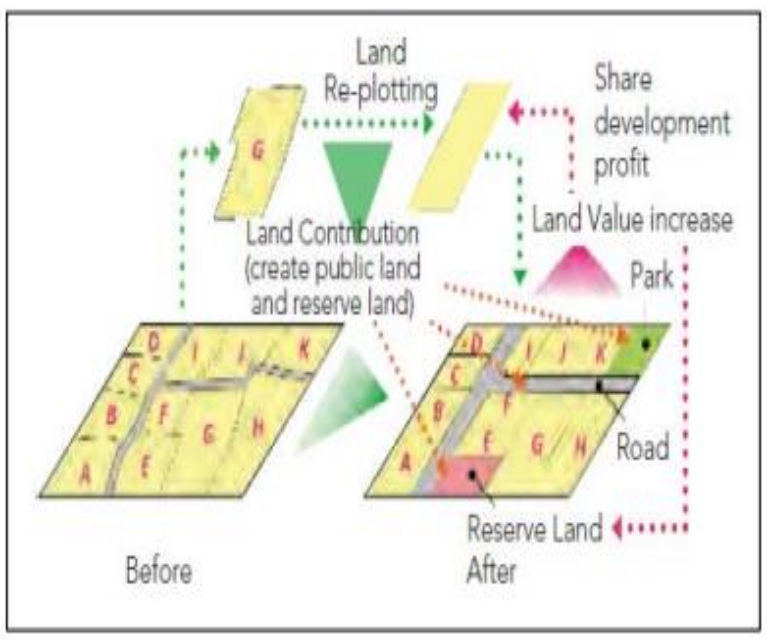

Fig. 5 Land before and after readjustment (Case Study Land Readjustment in Japan World Bank Group)

\section{Guided Land Development Schemes}

MMRDA had prepared a Guided Land Development (GLD) Scheme for Kalyan Growth Centre which was a variation of the LR Scheme. Its main objectives were to ensure,

- A fair return on investment to the private owner/developer,

- A relatively large proportion of serviced sites for allotment to low-income families; and at the same time
- Recover at least part of offsite infrastructure costs for the public agency. The responsibility for assembling land preparing the layout and developing the onsite infrastructure according to the guidelines is cast on the private developers. Further the developers are required to make available a certain number of small plots for low-income beneficiaries at a fixed price to public agencies. In this process the question of recovering the cost or of equitably distributing the betterment is circumvented. Such a scheme was considered to be possible as the land was notified for compulsory acquisition and the GLD was seen as an opportunity offered to landowners to develop their land in a manner that assures reasonable return on land. However, as the land acquisition proceeding itself was abandoned the GLD could not be put to practice. A similar scheme has been adopted in the Tamil-Nadu urban development project under the framework of the urban land (ceiling and regulation) act.

\subsection{Redevelopment of already developed areas}

\subsubsection{Land Sharing}

This technique is used in already developed areas or lands which have been encroached. The principle behind this has been that the land is shared equitably between the landowner and the tenants (quasi). The landowner develops the land in such a manner that the original inhabitants in that area are given shelter in the very same area lands for public facilities are made available to the planning agency and the remaining area is developed and sold freely in the market. This technique is widely used in 
Thailand and Indonesia to deal with relatively low-density squatter settlements.

\subsubsection{Slum Redevelopment}

The Development Control Regulations for Greater Bombay 1991 became effective in March 1991. Regulation 33 (10)-Appendix IV allows rehabilitation of the slum dwellers through owners/ developers/ co-operative housing societies. A total floor space index of up to 2.5 is granted with a condition that existing slum dwellers are rehabilitated at stipulated prices. The scheme is also applicable to land reserved for public purposes on the condition that land on a reduced scale is made available for the reserved purpose.

Similar strategies need to be developed to encourage recycling and urban renewal of old office and commercial districts in Mumbai including some of the heritage conservation areas.

\subsubsection{Fiscal Measures}

The emphasis of land policy has been on the large-scale public acquisition of land [12]. The potential of land and property taxation for achieving land policy objectives has not been given due importance. The objectives of land taxation could be

- Revenue generation for infrastructure investment although local authorities charge user fees for many services in certain types of services it is not possible to charge a user fee. A general tax is therefore important.

- Levy of such tax should cause equitable and progressive incidence on the taxpayers.

- Capturing land value gains (or so-called unearned income) that accrue on account of public investment infrastructure and
- The tax should help the optimal allocation of urban space - a particularly scarce resource in Mumbai.

\section{Conclusion}

There is scope for all nations rehearsing land rearrangement instruments to gain from each other. The underlying concept of land readjustment remains the same across borders. The concept of Land readjustment is primarily based on the increasing public-use of land while decreasing the size of private land. As a result, the private land size is reduced while their economic value increases due to the extra development which land readjustment with proper zoning plan brings. Meanwhile new built-up lots are developed, and municipalities take possession of the public land to provide new utilities and services as per requirement and need.

The potential use of land readjustment is to provide the land with infrastructure and amenities in peri-urban areas, which are likely to grow haphazardly in the absence of any regulated plan. This is the idea of reshaping or re-plotting a parcel of land developed with basic infrastructures, amenities and services like roads, parks, social infrastructure, and utilities.

Potential for local authorities to achieve replanning without the costs of compulsory land acquisition, and encourage better road layouts. When large-scale state intervention in society is less acceptable, hybrid measures which combine a measure of co-ercion with the opportunity for the land-owner to participate in the higher land values created by the scheme become more attractive. Also relates to a new philosophy of partnership between stake-holders, but with the opportunity to impose an element of 
compulsion14 through the declaration of the scheme. History of land management tools have their sponsors and enthusiasts, LR has had its advocates, can find their way into legislation and become established parts of the machinery of land law and procedure. Method cannot be separated from the social and legal culture. LR used for peri-urban development, and for man-made and natural disasters which created opportunities for increased public control over property rights. Outdated association with dominant Paternalistic state BUT potential tool to be used in partnership between LA \& JVC this depends upon cultural acceptance and opportunity. Thus, in Palestine there were historical roots in the Ottoman traditions of land readjustment Draw-backs: interference with private property rights esp Protocol. Choice of agency allows local community to retain some measure of control. Tradition of confidence in local authority (municipality or paternalistic state) \& no need for $\mathrm{CP}$. Situations where land-owners may wish to retain interest. Evermore turbulent world, post-Communist world, displaced populations. Drive towards land titling, improved valuation rules. Increasing importance of Human Rights with European Convention. Article 6 (right to a hearing) potential for local authorities to achieve re planning without the costs of compulsory land acquisition, and encourage a better road layout.

An important instrument/mechanism that has been forgotten in the process of attaching primacy to master plans is the Land Readjustment or Town Planning Schemes (TPS), which seeks to bring out development of areas through proposals that will have land pooling and readjustment after the development of adequate common infrastructure. Schemes, thereby, can also be used to attain the objectives laid down under master plan/ development plan in a gradual manner but with a well laid proposal developed at a rapid pace.

The Plot reconstitution and Land readjustment can be evaluated as a partnership model of urban land development against a set of criteria as below:

a) Stimulation of land supply for housing: Converted vacant or agricultural lands in urban fringes into serviced land for housing and accelerated the housing developments by plot reconstitution.

b) Improving the efficiency of land market: Plot reconstitution and Land readjustment acted as a planned intervention to open areas for market mechanisms. Being owner-based approach, simultaneous developments across the city facilitates a healthy competitive market.

c) Improving access to land for lowincome groups: Amendments to Plot reconstitution and Land readjustment could include provision for housing the poor, as is done in Gujarat.

d) Providing the basis for a more productive relationship between public and private sectors: Based on the experience of Plot reconstitution and Land readjustment and other approaches to participatory land developments, more democratic patterns of sharing are being experimented in India as well as in other countries.

e) Extent of public subsidy involved: Delays increase infrastructure costs while betterment charge may not match this, 
thereby involving additional financial resources to be deployed by the local authorities.

f) Constraints for replicability: Delays, lack of clear title of lands, disputes over valuation of land before and after scheme are some of the constraints. Fragmentation of land is another issue thereby requiring the Plot reconstitution and Land readjustment to deal with many landowners. Lastly, the Plot reconstitution and Land readjustment need to be undertaken not only for the implementation of a Development Plan but also for undertaking planned development of non-urban areas.

\section{References}

1. Frizzell R. (1979) The Valuation of Rural Property Lincoln College New Zeland.

2. Maguire D.J. (1991) An Overview and Definition of GIS In Maguire D $\mathbf{J}$ Goodchild M Rhind D (eds.) Geographical Information Systems: Principles and Applications pp.9-22 Vol.1 Longman London.

3. Rainer M.J. (1992) Detailed District Plan and Land Readjustment Project International Conference on Urban Development Policies and Projects Nagoya.

4. Archer R.W. (1992) Introducing the Urban Pooling/Readjustment Technique into Thailand to Improve Urban Development and Land Supply Public
Administration and Development Vol.12 pp. 155-174 John Wiley \& Sons Ltd.

5. Yomralioglu T. and Parker D. (1992) A New Approach to Land Reallocation Using GIS EGIS'92 Conference Proceedings Vol.II. p.1519-1520. The Netherlands.

6. Doebele W.A. (1982) Land Readjustment: A Different Approach to Financing Urbanization Massachusetts: D.C. Health and Company Lexington Books.

7. Larsson G. (1991) Land Registration and Cadastral Systems: Tools for Land Information and Management. Halsted Press Div. of John Wiley \& Sons, Inc. 605 Third Ave. New York, NY United States.

8. Yomralioglu, Tahsin \& Nisanci, Recep \& Yildirim, Volkan. (2007). An Implementation of Nominal Asset Based Land Readjustment

9. Chou T.C. and Shen S.K. (1982) Urban Land Readjustment in Kaohsiung In Doebele W.A (ed.) Land Readjustment: A Different Approach to Financing Urbanization Massachusetts: D.C. Health and Company Lexington Books.

10. Dale P.F and McLaughlin J.D. (1988) Land Information Management Oxford University Press New York.

11. Satoh T. (1986) Land Readjustment Problems in Implementation and 
Representation In Minerbi L. et.al.(ed.) Land Readjustment: The Japanese System University of Hawaii OGunn\&Hain/A Lincoln Institue of Land Policy Boston.

12. Kopardekar \& Keskar(1984). Land Pooling \& Readjustment Scheme: A Tool For Planned Urban Dev. Latest All Ind. Inst of Local Self Gov.

13. Uzun, B., Yomralioglu, T., \& Geoinformatics, F. P. T. (2005). An alternative approach to land compensation process to open urban arteries. 